\title{
Dynamic relationship between tourism, trade, infrastructure and economic growth: Empirical evidence From Malaysia.
}

\author{
Najat Nassor Suleiman* and Masoud Mohamed Albiman \\ School of Graduate Studies, Faculty of Economics and Management University Putra Malaysia Selangor.
}

Received 4 October 2013; Accepted 7 April 2014; Published April 2014

\begin{abstract}
This paper aims to investigate a positive inter-relationship between tourism, trade, infrastructure and economic growth. Through number of literature examine bilateral relationship between the variables; the literature has certified that tourism is the one of the key factor in trade and economic growth as well as trade is the key factors of tourism and economic growth. Furthermore, the literature found that infrastructure has a strong correlation between tourism, trade and economic growth. The results were mixed, some study found bidirectional and unidirectional relationship in bilateral model between tourism, trade, infrastructure and economic growth. Nevertheless, few studies carried out in term of analyzing the dynamic relationship between these four variables in Malaysia. In order to fill the gaping hole, the study analyzes the dynamic relationship between tourism, trade, infrastructure and economic growth in Malaysia. Therefore, the study used cointegration and granger causality tests to estimate the causal relationships between trade, tourism, infrastructure and economic growth in Malaysia using an annual data from 1999 to 2010. Findings show that trade has a significant impact in the long run on the economic performance of Malaysia. In the short run, statistical results show that there are causal relationships between trade, tourism, infrastructure and economic growth. The present results support growth-led tourism, tourism-led infrastructure, trade and economic growth, trade-led growth, tourism and infrastructure as well as infrastructure - led growth and infrastructure development in the short run. Overall, this study indicates that tourism, trade, infrastructure and economic growth interact and reinforce each other either directly or indirectly.
\end{abstract}

Key words: Economic growth, trade, tourism, infrastructure and Malaysia.

\section{INTRODUCTION}

Trade is believed to be among the factors that boost economic performance and tourism industry in Malaysia. The trade performance has increased since the end of 1980s exceeding two fold of the country's gross domestic product (GDP) and threefold after the year 2000. The rapid performance was due to the existence of agreements such as Asean free trade area (AFTA) that help to reduce trade barriers, increase competitiveness and boost export of goods and services. Half of the incomes in export industries

\section{*Corresponding a uthor E-mail: najatnassor@yahoo.com}

Author(s) agree that this artic le rema in pemanently open access under the terms of the Creative Commons Attribution Lic ense 4.0 Intemational Lic ense 
in Malaysia Market are based on electronic and electrical products, fat and vegetable oil, gas and petroleum products. However due to the global economic crisis, the demand of products especially in electrical and electronic major exports partner were slowdown. From this fact, it gives doubts whether the trade of goods and commodities is still a reliable source of Malaysia GDP growth. Therefore, the transformation to exports of manufactured goods to services sector such as tourism in order to diversify export portfolio.

Tourism plays a great role in stimulating the Malaysian economy since 1985 when the tourism industry was established under the ministry of culture, arts and tourism. In 2004, tourism was allowed to have its own ministry in order to ensure all development programs and activities are in line with the master plan. As a result, the growth of tourism in Malaysia increased rapidly in the last two decades. For example, the number of tourists arriving in Malaysia has increased from 3.11 million in 1985 to about 16.43 million in 2004 representing an average annual growth of $14.9 \%$. It is believed that, the good infrastructures in Malaysia are strong reason for the tourist arrivals.

Infrastructure development has long been recognized and understood by scholars and policymakers that infrastructure sector is the main inductive factor that support tourism arrivals and economic growth in general. In Malaysia the infrastructure investment took place in 1957 to 1970. However, the turning point for infrastructure development began in the mid-1970s with the third Malaysia Plan 1976 to 1980 .This plan helped in the significant increase in the sector's share of total development expenditure from $12 \%$ to $23 \%$. This change was due to the implementation of new economic policy (NEP) at the beginning 1970. Several literatures indicated that an infrastructure stimulates trade by reducing trade costs and increasing competition and boosting tourism by providing travelling convenience to tourists Fedderke and Garlick (2008).

Despite the fact that tourism, trade, infrastructure and economic growth are inter related each other, but many literatures analyze the relationship among these variables in bilateral system (Chang, 2008; Tang 2011; and Shan and Wilson (2001). Very few literatures studied the relationship among trade, tourism, infrastructures and economic growth in multivariate system (Samirdi and Salleh, 2011 and Lee, 2012). Since these variables are interrelated each other, their multivariate relationship is very important in economic policy and planning in Malaysia. Thus, against previous studies, this study aims to use time series method using autoregressive distributed lag (ARDL) method to analyze the relationship among trade, tourism, infrastructures and economic growth.

The paper is organized as follows. Subsequent section describes the literature review of inter-relationship between tourism, trade, infrastructure and economic growth.
Section 2 explains the empirical model, econo-metric methodology and the data employed in the analysis. Section 3 reports and discusses the results from the model estimation. Finally, Section 4 conclusion of the study.

\section{Review of literature}

Previous studies have mostly analyzed bilateral relationship between tourism, trade, infrastructure and economic growth. Several literatures were found to examine the relationship between tourism and economic growth. However, the results from these literatures were mixed. For example Dritsakis (2004) found cointegrating relationship and bidirectional causality between tourism and economic growth in Greece. In support of this view, Gunduz and Hatemi (2005) also found tourism led growth in Turkey. In contrast, Oh (2005) found no cointegration between tourism and economic growth.

Kim et al (2006) found a long run relationship between tourism and economic growth and bidirectional causality between variables in Taiwan. In supporting these views, Chang (2008), using heterogeneous panel cointegration, found unidirectional causality from tourism development to economic growth in Organisation for Economic Cooperation and development (OECD) countries whilst in non-OECD countries, found bidirectional causality between variables. On Bellaumi (2010) and Brida et al (2010) also found unidirectional causality from tourism to economic growth in Tunisia and Uruguay respectively. Furthermore, Tang (2011) and De MelloSampayo and de Sousa-Vale $S$ (2011) also found unidirectional causality from tourism to economic growth in Malaysia and north European countries respectively.

On the other hand, few studies examined relationship between international trade and tourism and their results were mixed. For example, between Australia and its main trading partners, Kulendran and Wilson (2000) found a cointegration relationship between their international tourism and international trade, whilst the results of causality remained mixed. Shan and Wilson (2001) however, found bidirectional causality between international tourism and international trade between China and its main trading partners.

On the other hand, Khan et al (2005) supported the results of Kulendran and Wilson on the long run relationship between tourism and international trade; however, they contradicted Kulendran and Wilson in the case of causality, since they found no causality between the two variables. On the other hand, Fry et al (2010) found a long run relationship between international tourism and international trade in South Africa. Fry et al (2010) together with Semra and Gunay (2010) both found bidirectional causality between tourism and international trade whilst Kadir and Jusoff (2010) found unidirectional causality from import, export, total trade to 
international tourism in Malaysia.

Studies on the relationship between infrastructure and tourism, trade and economic growth have revealed mixed result. Canning and Pedroni (1999) found bidirectional causality between infrastructure and GDP per capita in many countries. In a broader study, Esfahami and Ramirez's (2003) cross country study found substantial contribution of services infrastructures towards GDP per capita for developing and developed countries. On a different perspective, most literatures found infrastructures to have a positive relationship with trade flow. For example, studies by Nordas and Pier Martini (2004) and Tanzi (2005) both found significant positive impact by telecommunication and transport cost on trade flows. In the study by Francois and Machim (2007), it was eminent that communication costs affects trade cost, resulting in an improvement in such infrastructure exerts a positive effect on trade flows. On top of that, Ahmad et al (2011) also suggested that telephones (fixed or mobile) and personal computers have significant positive impact on bilateral trade between Malaysia and its main trading partners.

However, inhnmm a more recent study by Samirdi and Salleh (2011), an extended model was attempted by combining two industries together namely tourism and trade in Malaysia. Likewise, Lee (2012) analyzed the causal relationship between three variables namely tourism, trade and income in Singapore. Generally, the majority of research findings strongly agree that there exist relationships between trade and economic growth, tourism, growth, infrastructure and economic growth.

Having looked at Malaysian literature, this study intended to provide a bigger perspective in the Malaysian economic context by incorporating a nother variable, namely infrastructure into its empirical model.
The inclusion of this variable is important as most empirical models in earlier papers on Malaysian economy have omitted it yet studies in other countries clearly demonstrated the importance of this variable on economic growth, trade and tourism.

\section{DATA AND METHODOLOGY}

The data set consists of Malaysia's time series observations on total trade (TRD), GDP, Infrastructure (INTR) the proxy used is telephone line and total international visitor arrivals (TOU). TRD is obtained by summing up export and import to GDP. The secondary data was extracted from world development indicators statistical database of 2010 for the time period of 1995 to 2010. The objective of the study is to analyze the existence of a dynamic relationship between tourism, trade, infrastructure and economic growth in Malaysia. The model can be formulated as follows:

$\mathrm{GDP}_{\mathrm{t}}=\mathrm{C}+w_{1} \mathrm{TOU}_{\mathrm{t}}+w_{2} \mathrm{TRD}_{\mathrm{t}}+w_{3} \mathrm{INFR}_{\mathrm{t}}+\varepsilon{ }_{1 t}$ 1

The method used for the estimation is the autoregressive distributed lag (ARDL). The application of ARDL consists of three stages. First, unit root test are employed to check for stationary of the variables. The tests used are of augmented dickey-fuller (ADF) and phillips perron (PP) unit root tests. Thus, when the variables are stationary after first differencing, the next stage is to test for cointegration. The method used is the ARDL cointegration procedure that was proposed by Pesaran et al (2001). According to Pesaran and Shin (1999), establishing the correct selection of lags may be able to ward off the problems of serial correlation and endogeneity in an ARDL model. The procedure also works well with small sample. The method distinguishes dependent from independent variables. Also, both $\mathrm{I}(0)$ and $\mathrm{I}(1)$ variables may avoid the pre-testing problem related with conventional method. The bounds test investigates whether a cointegrating relationship exists in the following unrestricted error correction model:

$$
\begin{aligned}
& \Delta G D P_{t}=C+w_{1} G D P_{t-1}+w_{2} \text { TOU }_{t-1}+w_{3} T_{R-1}+w_{4} \operatorname{INFR}_{t-1}+\sum_{i=1}^{p} \alpha_{1 i} \Delta G D P_{t-i}+\sum_{i=1}^{p} \alpha_{2 i} \Delta T O U_{t-1} \\
& +\sum_{i=1}^{p} \alpha_{3 i} \Delta \operatorname{TRD}_{t-1}+\sum_{i=1}^{p} \alpha_{4 i} \Delta I N F R_{t-1}+\varepsilon_{1 t} \ldots \ldots \ldots \\
& \Delta \text { TOU }_{t}=C+x_{1} \text { TOU }_{t-1}+x_{2} G_{t-1}+x_{3} \operatorname{TRD}_{t-1}+x_{4} \text { INFR }_{t-1}+\sum_{i=1}^{p} \alpha_{1 i} \Delta G D P_{t-i}+\sum_{i=1}^{p} \alpha_{2 i} \Delta T U_{t-1} \\
& +\sum_{i=1}^{p} \alpha_{3 i} \Delta T R D_{t-1}+\sum_{i=1}^{p} \alpha_{4 i} \Delta \operatorname{INFR}_{t-1}+\varepsilon_{2 t} \\
& \Delta T_{t}=C+y_{1} \operatorname{TRD}_{t-1}+y_{2} \text { TOU }_{t-1}+y_{3} \text { GDP }_{t-1}+y_{4} \text { INFR }_{t-1}+\sum_{i=1}^{p} \alpha_{1 i} \Delta G D P_{t-i}+\sum_{i=1}^{p} \alpha_{2 i} \Delta T O U_{t-1} \\
& +\sum_{i=1}^{p} \alpha_{3 i} \Delta T R D_{t-1}+\sum_{i=1}^{p} \alpha_{4 i} \Delta \operatorname{INFR}_{t-1}+\varepsilon_{3 t} \\
& \Delta I N F R_{t}=C+z_{1} \text { INFR }_{t-1}+z_{2} \text { TOU }_{t-1}+z_{3} T_{R D_{t-1}}+z_{4} G_{t-1}+\sum_{i=1}^{p} \alpha_{1 i} \Delta G D P_{t-i}+\sum_{i=1}^{p} \alpha_{2 i} \Delta T O U_{t-1} \\
& +\sum_{i=1}^{p} \alpha_{3 i} \Delta T R D_{t-1}+\sum_{i=1}^{p} \alpha_{4 i} \Delta I N F R_{t-1}+\varepsilon_{4 t}
\end{aligned}
$$


Equation 1, 2, 3 and 4 are traditional ARDL model with the $\Delta$ represents the difference of the variable, $p$ is the number of lags and $\varepsilon$ is the error term. Pesaran et al (1996) provided two assumptions; the first being all the variables are of $\mathrm{I}(0)$ and the second is that all of them are I(1). The null hypothesis of no cointergration relationship is expressed as $\mathrm{HO}=\mathrm{b}_{1}=\mathrm{b}_{2}=\mathrm{b}_{3}=$ $b_{4}=0$ against $b_{1} \neq b_{2} \neq b_{3} \neq b_{4} \neq 0$. The null hypothesis of no cointegration is rejected if the computed F-statistic obtained from each null hypothesis exceeds the respective upper critical value. If the computed F-statistic is lower than the respective lower critical value, the null hypothesis is accepted. If the computed Fstatistic falls inside the lower and upper critical values, no conclusive decision can be made unless the order of integration of the variables under consideration is known.

The third stage is the estimation of the short run and the speed of adjustment of the variables. Granger causality test was employed to estimate the model where the variables were cointegrated. The causality can be either unidirectional or bidirectional. To implement the Granger causality test, the following models are specified:

$$
\begin{aligned}
& \Delta G D P_{t}=a_{o}+\sum_{i=1}^{p} \alpha_{1 i} \Delta G D P_{t-i}+\sum_{i=1}^{p} \alpha_{2 i} \Delta T O U_{t-1}+\sum_{i=1}^{p} \alpha_{3 i} \Delta T R D_{t-1}+ \\
& \sum_{i=1}^{p} \alpha_{4 i} \Delta I N F R_{t-1}+\delta_{1} E C T_{t-1}+\mu_{1 t} \\
& \Delta \text { TOU }_{t}=b_{o}+\sum_{i=1}^{p} \alpha_{1 i} \Delta \operatorname{TOU}_{t-i}+\sum_{i=1}^{p} \alpha_{2 i} \Delta G D P_{t-1}+\sum_{i=1}^{p} \alpha_{3 i} \Delta T R D_{t-1} \\
& +\sum_{i=1}^{p} \alpha_{4 i} \Delta I N F R_{t-1}+\mu_{1 t} \\
& \Delta \operatorname{TRD}_{t}=b_{o}+\sum_{i=1}^{p} \alpha_{1 i} \Delta \operatorname{TRD}_{t-i}+\sum_{i=1}^{p} \alpha_{2 i} \Delta G D P_{t-1}+\sum_{i=1}^{p} \alpha_{3 i} \Delta \operatorname{TOU}_{t-1} \\
& +\sum_{i=1}^{p} \alpha_{4 i} \Delta I N F R_{t-1}+\delta_{1} E C T_{t-1}+\mu_{1 t} \\
& \Delta \operatorname{INFR}_{t}=b_{o}+\sum_{i=1}^{p} \alpha_{1 i} \Delta \operatorname{INFR}_{t-i}+\sum_{i=1}^{p} \alpha_{2 i} \Delta G D P_{t-1}+\sum_{i=1}^{p} \alpha_{3 i} \Delta T R D_{t-1} \\
& +\sum_{i=1}^{p} \alpha_{4 i} \Delta T O U_{t-1}+\mu_{1 t}
\end{aligned}
$$

\section{FINDINGS AND DISCUSSION}

In this section, we discuss the findings based on ARDL. Table 1 presents the results of the unit root tests, ADF and PP. Results show that the null hypothesis of unit root could not be rejected at level. However, after taking first difference the null hypothesis of unit root was rejected. Therefore, the results strongly indicate that the variables were stationary at first difference I (1). The results are consistence with the finding of Samirdi and Salleh (2011), that conclude all variables are each integrated with another (1). (Table 1)

Moving further in analyzing cointegration relationship between the variables mention earlier, the test requires the selection of maximum lags. The values of $p$ are selected based on Schwarz' Bayesian information criterion (SIC). However, because of a relatively small sample size and annual data used in this study, the maximum possible values of $p$ are set at 1 . The test reflects cointegration among variables in Equation (1) and (3). This is because $F$-statistic exceeded the upper bound critical value at $5 \%$ level. This implies that the null hypothesis of no cointegration is rejected and that there is a strong evidence of cointegration relationship between the variables. The results are consistence with finding of Samirdi and Salleh (2011) and Lee (2012). Table 2. The results of Granger causality test.

Table 3, represents short run relationship between the variables. The results show that there is unidirectional relationship between the variables. The statistical results show that GDP Granger-causes TOU, the results are consistence with the finding of Kim et al (2006) and Brida et al (2008). TRD causes GDP, the results are consistence with the finding of Wong (2004), TRD causes TOU results are in line with the finding of Kadir and Jusoff (2010) found unidirectional relationship between TRD and INFR and TRD granger cause INFR the results are consistence with the finding of Feddereke and Luiz (2005) and Canning and Pedroni (1999), and TOU causes INFR the results are consistence with the finding of Nazari and Nasrindoost (2010), TOU granger cause TRD, the results are consistence with the finding of Semra and Gunay (2010) and Fry et al (2010) and TOU causes economic 
Table 1. Unit Root Results (Level and First difference)

\begin{tabular}{lcccc}
\hline \multirow{2}{*}{ Variable } & \multicolumn{2}{c}{ Augmented Dickey Fuller (ADF) } & \multicolumn{2}{c}{ Phillips Perron (PP) } \\
\cline { 2 - 5 } & $\begin{array}{c}\text { Constant } \\
\text { Without Trend }\end{array}$ & $\begin{array}{c}\text { Constant With } \\
\text { Trend }\end{array}$ & $\begin{array}{c}\text { Constant Without } \\
\text { Trend }\end{array}$ & $\begin{array}{c}\text { Constant } \\
\text { Trend }\end{array}$ \\
\hline Level & & & & -2.732 \\
LGDP & -0.463 & -2.777 & -0.304 & $(0.239)$ \\
& $(0.873)$ & $(0.225)$ & $(0.903)$ & -2.665 \\
LTRD & -0.978 & -2.426 & -0.749 & $(0.261)$ \\
& $(0.732)$ & $(0.353)$ & $(0.804)$ & -3.246 \\
LTOU & -0.335 & -3.169 & -0.141 & $(0.113)$ \\
& $(0.897)$ & $(0.136)$ & $(0.927)$ & -4.431 \\
LINFR & -2.017 & -2.865 & -1.398 & $(0.016)$ \\
First Difference & $(0.276)$ & $(0.201)$ & $(0.554)$ & \\
LGDP & & & & $-7.842^{*}$ \\
& $-5.392^{*}$ & $-5.829^{*}$ & $-7.432^{*}$ & $(0.000)$ \\
LTRD & $(0.000)$ & $(0.003)$ & $(0.000)$ & $-5.525^{*}$ \\
& $-3.343^{*}$ & $-3.848^{*}$ & $-4.154^{*}$ & $(0.003)$ \\
LTOU & $(0.034)$ & $(0.048)$ & $(0.007)$ & $-4.117^{*}$ \\
LINFR & $-4.205^{*}$ & $-4.547^{*}$ & $-4.634^{*}$ & $(0.029)$ \\
& $(0.009)$ & $(0.022)$ & $(0.003)$ & -2.566 \\
& $-2.792^{* *}$ & -1.951 & -3.783 & $(0.297)$ \\
\hline
\end{tabular}

Note: ${ }^{* *}$ and ${ }^{*}$ denotes significance at $10 \%$, and $5 \%$ levels, respectively. The figure in parenthesis (...) represents probability.

Table 2. The results of Granger causality test.

\begin{tabular}{llcc}
\hline Equation & $\mathbf{P}$ & HO & F-value \\
\hline 1 & 1 & $\mathrm{w} 1=\mathrm{w} 2=\mathrm{w} 3=\mathrm{w} 4=0$ & $41.77^{*}$ \\
2 & 1 & $\mathrm{x} 1=\mathrm{x} 2=\mathrm{x} 3=\mathrm{x} 4=0$ & 2.55 \\
3 & 1 & $\mathrm{y} 1=\mathrm{y} 2=\mathrm{y} 3=\mathrm{y} 4=0$ & $8.04^{*}$ \\
4 & 1 & $\mathrm{z} 1=\mathrm{z} 2=\mathrm{z} 3=\mathrm{z} 4=0$ & 4.63 \\
\hline
\end{tabular}

Note: ${ }^{*}$ and ${ }^{* *}$ denotes significance at $5 \%, 10 \%$, respectively. Number in parenthesis ( ) indicate $p$ value

Table 3. Granger causality results based on ARDL

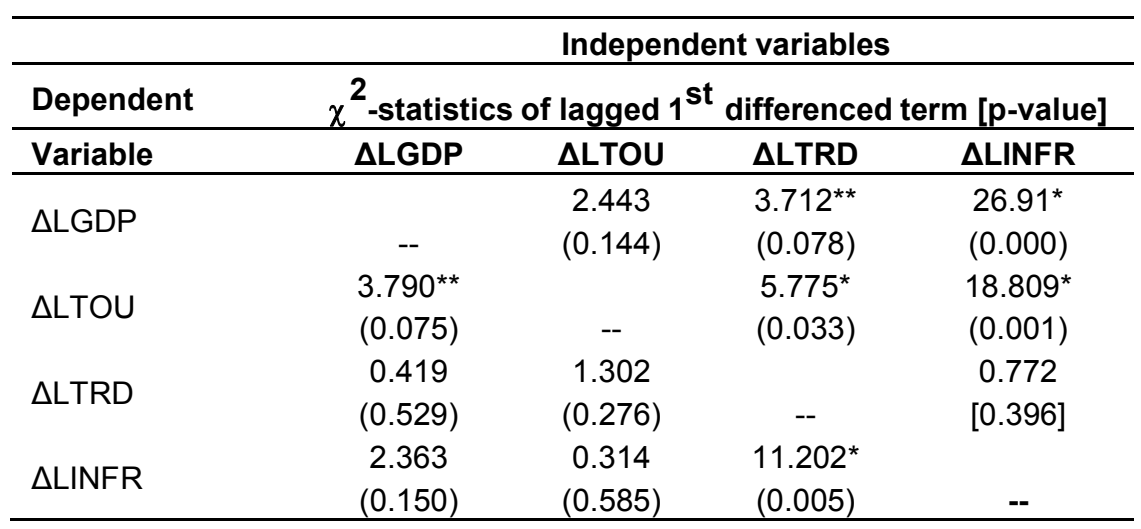

Note: ${ }^{* *}$ and * denotes significance at $10 \%$ and $5 \%$ levels, respectively. The figure in the parenthesis $(\ldots)$ represents $p$-value. 


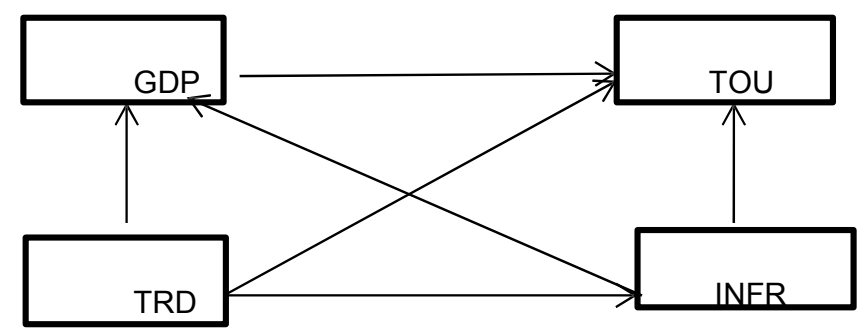

Figure 1. Summary of the causal channels between the variables.

variable in economic, tourism, trade and infrastructure development of Malaysia. The causal channels can be summarized as below. (Figure 1)

\section{CONCLUSION}

This paper examines the relationship between tourism, trade, infrastructure and economic growth. In contrast with previous scholars, this study is distinguished in that it is not constrained to the basic two- variable case. It addresses this issue with a four-variable model. It focuses on the short-run dynamic interactions of tourism arrive, trade, infrastructure and economic growth of Malaysia. The results suggest that the dynamic interaction of these four variables is complex. The results suggest a growth-led tourism, a tourism-led infrastructure, trade and economic growth, a trade-led growth, tourism and infrastructure as well as an infrastructureled growth and infrastructure development in the short run. The expansion of Malaysian economy, in terms of a higher GDP, will have direct and indirect effects on the tourism industry. GDP Granger-causes tourism directly as higher economic growth allows for upgrading and maintenance of existing attractions, and infrastructure (Lee, 2008). GDP also has an indirect impact on tourism through trade activities. This can be supported by the suggestion of Kulendran and Wilson (2000) that business travelers support the tourism activities in a country.

Finally, infrastructure has a direct impact on tourism and trade. As argued by Francois and Machim (2007), good infrastructure reduces the cost of transportation of goods and services as well attracts tourism due to the ease in connecting from one place to another. The findings suggest that there is a need for policy makers to focus on promoting trade openness to capitalize the effect of international tourism on economic growth. In summary, this study suggests that the idea of excluding infrastructure and just focus on the role of international tourism as an engine of growth is truly misleading. Current evidence does not provide a direct effect of tourism on economic growth. Overall, this study indicates that tourism, trade, infrastructure, and economic growth dynamically interact and reinforce each other's effect either directly or indirectly.

\section{REFERENCE}

Ahmad NA, Ismail NW, Law SH (2011). The Role Of ICT Infrastructure On Malaysia Trade. Int. J. Econ. Manag. 5(1):140148.

Balaguer J, Cantavella-Jorda. M (2002). Tourism As A Long-Run Economic Growth Factors: The Spanish Case. Appl. Econ. 34(7):877-884

Bellaumi M (2010). The Relationship Between Tourism Receipts, Real Effective Exchange Rate And Economic Growth In Tunisia. Int. J. Tourism Res. 12(5):550-560.

Brida JG, Lanzilotta B, Lionetti SR (2010). Research Note, The Tourism Led Growth Hypothesis For Uruguay. Tourism Econ. 16(3):765-771.

Canning D, Pedroni P (1999). Infrastructures and long run economic growth. paper presented at the econometrics society, Summer Meeting Madison Wisconsin.

De Mello-Sampayo, F, de Sousa-Vale S (2011). Tourism and Growth in European Countries: Model Specification And Panel Data Analysis. Appl. Econ. Q. 57(4):302-324. http://ejournals.dunckerhumblot.de/doi/abs/10.3790/aeq.57.4.303?journalCode=aeq

Dritsakis N (2004). Taiwan As A Long Run Economic Growth Factor: An Empirical Investigation For Greece Using Granger Causality Analysis. Tourisms Econ. 10(3):305-316.

Esfahami HS, Ramirez MT (2003). Institutions, Infrastructures And Economic Growth. J. Dev. Econ. pp..443-477.

Fedderke J, Garlick R (2008). Infrastructure development and economic growth In South Africa: A Review of the accumulated evidence. Policy school of economics, University of Cape-Town and Econ. Res. South Afr. p.12.

Francois J, Machim M (2007). Institutions, Infrastructures and Trade. Policy Research Working Papers pp.38. http://elibrary.worldbank.org/doi/book/10.1596/1813-9450-4152

Fry D, Saayman A, Saayman M (2010). The Relationship Between Tourism And Trade In South Afr. J. Econ. 78(3): 287-306.

Gunduz L, Hatemi-J A (2005). Is The Tourism Led Growth Hypothesis Valid For Turkey? Appl. Econ. Lett. 12(8):499-504.

Jordaan AC, Eita JH (2007). Export And Economic Growth In Namibia: A Granger Causality Analysis. South Afr. J. Econ. 75:540-547.

Kim HJ, Chen M, Jang S (2006). Tourism Expansion And Economic Development: The Case Of Taiwan. Tourisms Manage. 27:925-933.

Kulendran N, Wilson K (2000). Is There A Relationship Between International Trade And International Travel? Appl. Econ. 32(8):1001-1009.

Kumo WL (2012). Infrastructure Investment And Economic Growth In South Africa: Agranger Causality Analysis. Working Paper African Development Bank Group.

Lee CG (2012). Tourism, Trade and Income: Evidence From Singapore. Anatolia: Int. J. Tourisms. Hosp. Res. 23(3):348-358. http://www.tandfonline.com/doi/abs/10.1080/13032917.2012.70159 6\#.U1lwtIVdVQ0

Nordas KH, Pier M (2004). Infrastructure and trade. staff working Papers ESRD-2004-04, Economic Research and Statistics Division, World Trade Organization, Geneva.

Nazar MA, Nasrindoost M (2010). The role of technical infrastructure in the quality of relationship between tourism and economic growth in Iran World. Appl. Sci. J.10:146-152.

Oh CO (2005). The Contribution Of Tourism Development To Economic Growth In: The Korea Economy. Tourism Manage. 26:39-44.

Pesaran H, Smith R, Im K (1996). The econometrics of panel data: A Handbook of the theory with applications, Kluwer Academic Publishers, Dordrecht pp.145-195.

Pesaran MH, Shin Y, Smith RJ (2001). Bounds testing approaches to the analysis of level relationships, J. Appl. Econom. 16:289326.

Sarmidi T, Salleh NH (2011). Dynamic Inter-Relationship Between Trade, 
Economic Growth And Tourism In Malaysia, Int. J. Econ. Manag. 5(1):38-52.

Semra TE, Gunay S (2010). Relationship Between Tourism And Trade In Turkey. Int. Conf. Appl. Econ-ICOAE.pp. 591-596.

Shiu A, Lam P (2004). Electricity Consumption and Economic Growth in China 35(1):47-54

Shan J, Wilson K (2001). Causality Between Trade And Tourism Empirical Evidence From China. Appl. Econ. Lett. 13(5):319-324.

Tang CF (2011). Tourisms, Real Output And Real Effective Exchange Rate In Malaysia. A View Rolling Sub Samples-MPRA Munich, Germany: University Library of Munich http://mpra.ub.unimuenchen.de/29379/1/MPRA_paper_29379.pdf

Tanzi V (2005). Building Regional Infrastructures In Latin America. Insituto Para La Integracion De America Latina Yel Caribe (INTAR), Working Paper SITI 10. Bueros Aires :INTAR
Tekin RF (2012). Economic Growth, Exports And Foreign Direct Investment In Least Developed Countries: A Panel Granger Causality Analysis. Econ. Model. 29:868-878.

Wong H (2004). Terms Of Trade And Economic Growth In Malaysia. Labuna Bull. Int. Bus. Financ. 2(2):105-122.

Zhang DW (2010). How Dependent Is The Chinese Economy On Exports And In What Sense Has Its Growth Been Export Led? J. Asian. Econ 21:481-496. 